\title{
Determination of Awareness of Piracy Level on Educational Institutions- A Questionnaire Based Study
}

\author{
Shah Nazir ${ }^{1 *}$, Anwar Hussain1, Sara Shahzad ${ }^{2}$, Hanif Ur Rehman1, Islam Zada ${ }^{2}$, Muhammad Ahsan $^{1}$, \\ Zohaib Ahmad1, and Abdullah Khan ${ }^{1}$ \\ 1Department of Computer Science, University of Swabi, Pakistan \\ 2Department of Computer Science, University of Peshawar, Pakistan \\ Corresponding author-snshahnzr@gmail.com
}

\section{Abstract}

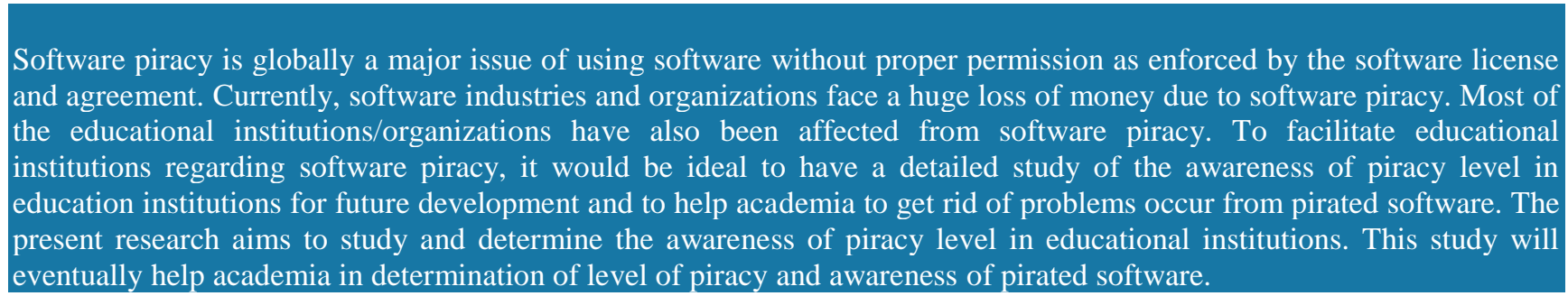

Keywords: Educational institutions, Software Piracy, Software Theft Detection.

Received on 05 December 2017, accepted on 16 February 2018, published on 10 April 2018

Copyright (C) 2018 Shah Nazir et al., licensed to EAI. This is an open access article distributed under the terms of the Creative Commons Attribution licence (http://creativecommons.org/licenses/by/3.0/), which permits unlimited use, distribution and reproduction in any medium so long as the original work is properly cited.

doi: 10.4108/eai.10-4-2018.154450

\section{Introduction}

The software industry is worsely affected from the piracy of software that results in huge financial loss to the copyright holder. The pirates earn huge amount of money and profit by the illegal usage of softwares. Software piracy is performed in several ways, including hard-disk loading, soft lifting, counterfeit goods, rental software and bulletin board piracy [1-4]. The licensed software carries so many advantages such as; assurance of the disk carrying no virus, regular software upgrades, consistent technical support, complete documentation and quality assurance, while the pirated software fails to have these advantages [5]. The educational institutions are using software for their academic needs. The use of pirated software ultimately leads toward a big chance of failure. On the other hand, educational institutions are also facilitated with some commonly in use original software by the higher education commission. Most of the institutions are not well aware of these facilities. This unawareness leads them toward a huge loss. Numerous advanced techniques are used for the detection and prevention of software theft. These techniques include, software watermarking and software fingerprints [613]. The concept of software birthmark has been developed after watermark and fingerprints and is now widely used as a technique to detect software theft [14-19]. Moreover, the software birthmark is an inimitable quality of software used to detect software theft. The present research work contribution is to determine the awareness of piracy level in educational institution(s) which is a major concern for modern academia. The results of current research work will eventually help organizations/institutions to use original licensed software and stop to use pirated software, as it might bring losses to organizations/institutions where you are working. 


\section{Background}

The software industry has been suffered from huge financial loss due to piracy of software. Piracy of software is performed by end-users as well as by the dealers. It is in fact a problem of illegal copying, installation, use, distribution and sale of software in any way other than that is expressed in the license agreement. It causes serious problems which hinder the success of the international software industry. Pirates gain easy benefits from the sale of pirated software which ultimately affects the business of the software industry. The original licensed software offers a number of high valued benefits to the customers including assurance of software quality, availability of upgrades, technical documentations and lastly by less bandwidth consumption. Contrary to this, pirated software does not provide such kind of facilities. When an organization is using pirated software, there will be risk of failure of the system, which might put the organization at risk of huge financial loss [5] [15]. Previously, various researchers worked to promote conscious efforts during software development so as to detect and prevent software piracy. For educational institutions, it is also necessary to have a mechanism under which the original licensed software can be used for academic needs. There should also be an awareness of discouraging pirated software. The proposed research work is an endeavour toward highlighting the current issue related to awareness and benefits/drawbacks of original and pirated software.

\section{Methodology}

The following sub-sections briefly discusses the methodology and results and discussion section of the paper.

\subsection{Aawarness and piracy in educational institutions}

Software piracy is a global problem of using software without any appropriate software license and agreement. The software industry faces a huge loss of money due to piracy issue. The educational institutions are also affected from the concerned issue. The present research provides a detailed study of the determination of awareness of piracy level in education institutions that will help in the development of academia in future. This research aims to investigate the awareness level of piracy of software performed in educational institutions. The present research certainly identified the level of awareness raised from software piracy in educational institutions. The educational institutions and academicians are using software for their academic purposes and needs. The use of pirated software in educational institutions might ultimately lead toward failure. The educational institutions have been also facilitated with some commonly in use, original software by the higher education commission. Most of the institutions are not fully aware of these facilities, and ultimately this unawareness might put them into a big possibility of loss. Extensive spending on public in education reduces software piracy as well as gives awareness to the pirated software users. In this research a questionnaire based study was performed for analyzing the level of awareness of piracy performed in educational institutions. A questionnaire based study and data collection was performed from different public sector educational institutions.

\subsection{Results and analysis}

To identify the issues related to software piracy, questionnaire containing 15 questions were given to the participants. A total of 68 numbers of participants responded for the questionnaire including 41 number of faculty members, 19 students and 8 from other profession. Questionnaire was aimed to capture why people use pirated software and the reasons behind it. Survey was conducted by considering three aspects of piracy. These are current awareness of participants about piracy, exiting level of software piracy, and reasons for software piracy. Most of the participants were faculty, and are in the age between $18-35$. Details regarding these aspects are given below;

\subsubsection{Awareness}

Awareness about software piracy has been assessed by asking question from participants about software piracy, HEC facility, seminar/workshop attended, piracy penalties, disadvantages and piracy issue importance. Results statistics are shown in Figure1, Figure 2, Figure 3, Figure 4, Figure 5, Figure 6 Figure 7 and Figure 8. The following conclusions were drawn;

- Survey results show that most of the participants know software piracy, Statistics show $70.6 \%$ of the participant are aware while $29.4 \%$ don't know.

- $64.7 .3 \%$ of participants were aware of the HEC facility about providing software to student and faculty.

- Based on the statistics only $11.8 \%$ participants have attended any seminar on software piracy issue.

- Most of the participants i.e., $58.8 \%$ believe that pirated software does have disadvantages.

- $76.5 \%$ of participants are unaware of the penalties given for software piracy while $23.5 \%$ knows about it.

- Participants do believe that software piracy is an important issue. Only $17.6 \%$ participants don't consider it an important issue.

\subsubsection{Existing software piracy}

Along with the knowledge of software piracy, still pirated software rate is high. Statistics shows that $70.6 \%$ of participants are using pirated software. Rate of software from unofficial sources is $70.7 \%$ which shows the piracy of software. Friends of the participants are mostly using pirated software and statistics shows that $35.3 \%$ don't use registered software along with the $64.7 \%$ participant belief that only few of their friends use official and most 
of other are using pirated version. Even participant select software not the features but actually on the basis of cost. $70 \%$ participants select choose software which has lower cost while $29.4 \%$ choose it by the number of feature the software provide.

\subsubsection{Reasons}

Participants were asked about how piracy can be reduced. Statistics ties between two factors i.e., awareness and software prices. Even the statistics are not exactly equal but still difference is not too much significant. The $58.8 \%$ suggest awareness should be given to people about piracy issue while $41.2 \%$ suggest that the prices of software should be lower. Possible reason highlighted for software piracy is nearly the same as above. $52.9 \%$ participant believe that awareness is the main reason and people do piracy, they are not aware of penalties along with disadvantages, while $47.1 \%$ believe that the main reason is the high prices.

\section{Proposed suggestion}

Piracy is an important issue and can be tackled by following suggestions based on the results obtained from survey.

- $\quad$ Simple method of payments- In the survey, very small number of participant was getting software by using online payment system. Other depends on the traditional method of buying CD/DVD. Most of the student do not use credit card. It is important to provide more easy ways of payments.

- By reduction of Prices- Most of the participant suggest that the piracy can be reduced by lowering the prices of software. It can be achieved by lowering the prices of different software based on the occupation. HEC already provided different plans, but still it needs to be more discounted.

- HEC needs to arrange seminars on the issue of software piracy. These seminars should highlight the penalties given to the persons doing piracy of software and the awareness about piracy disadvantages

- Most of the participant doesn't agree that their institution provides any free software facility to them. It is important to provide facility all the HEC registered academic institutions.

Figure 1, Figure 2, Figure 3, Figure 4, Figure 5, Figure 6, Figure 7 and Figure 8 shows the details of questions' responses provided and their relevant statistics.

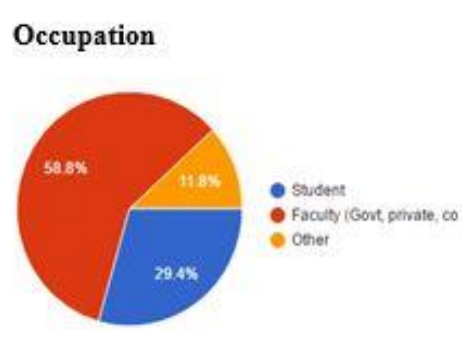

User's Knowledge about software Piracy

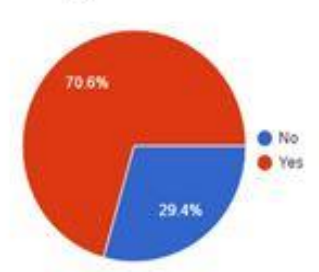

Participants knowledge about HEC facility
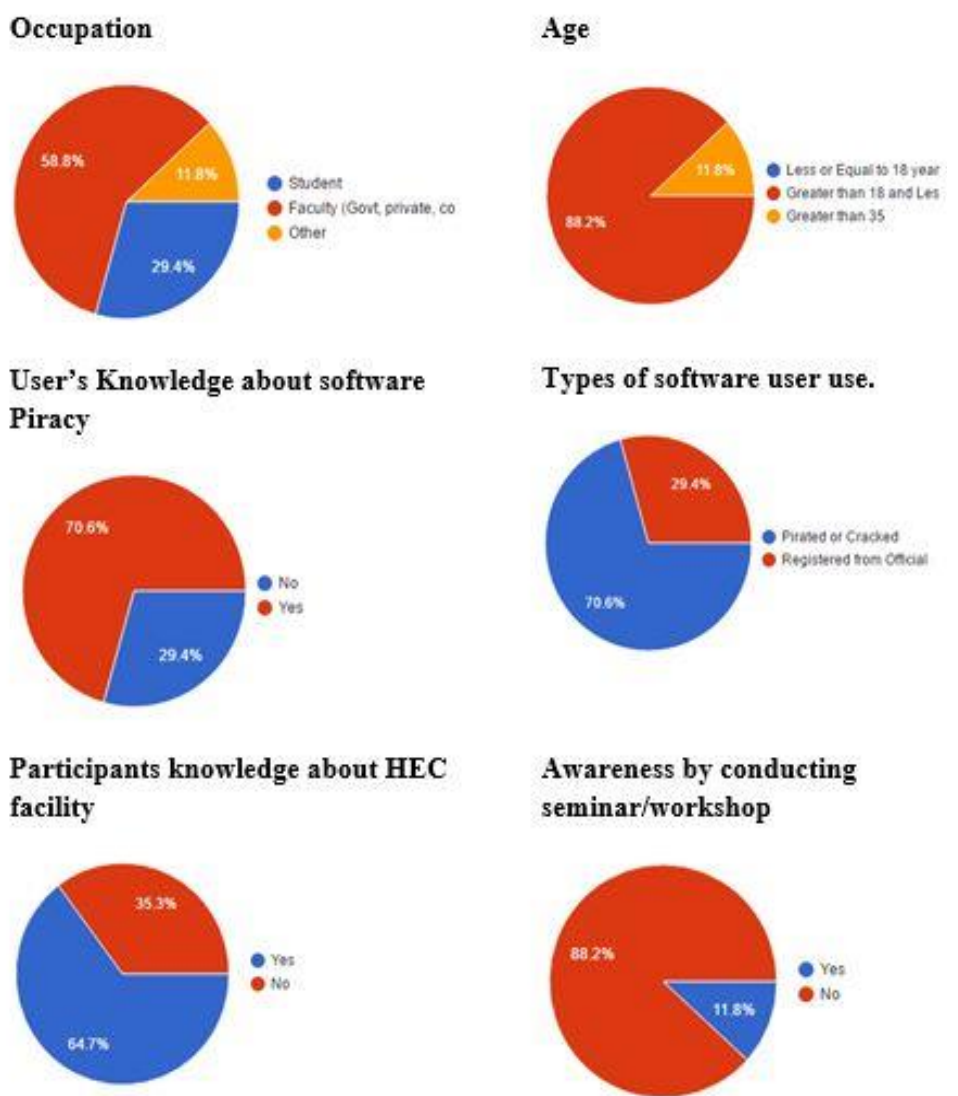

Types of software user use.

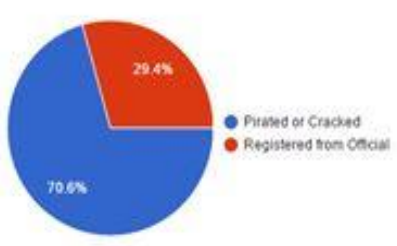

Awareness by conducting seminar/workshop

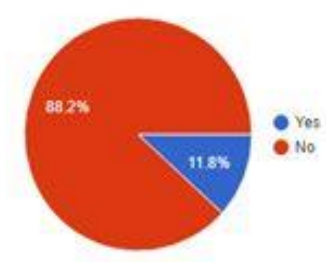

Figure 1: Users' Responses

For identification of whether the responses ration inside questions are significantly different or not, we have apply Non parametric one sample test. The tests are run on IBM SPSS software, and the results are listed in Figure 6.

In Figure 6, we can see that null hypothesis is rejected for all the questions responses except two i.e., tie between users awareness and high prices of software. As above mentioned that the main factor shown by the user is the economic factor along with lack of awareness. The difference is not significant which restrict us to decide what more important factor of software piracy is. At that point, both have almost equal contribution in the issue of software piracy. 
Method by which participant register software

Scope of piracy of participants friends

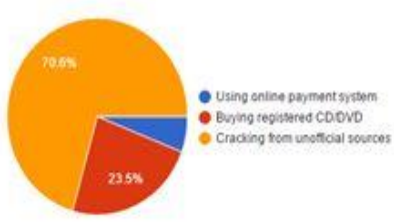

Awareness about piracy harmfulness

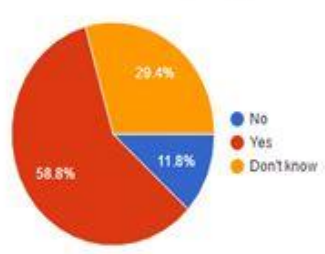

How much user consider piracy issue importance

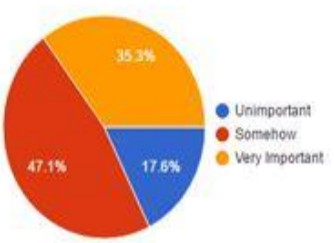

\section{Figure 2: Users' Responses}

Reason of piracy from user's perspective

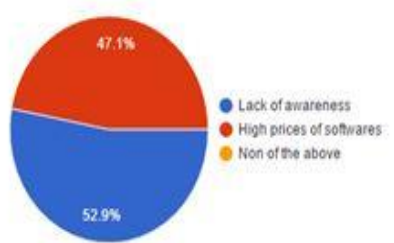

Criteria of selection software from user's perspective

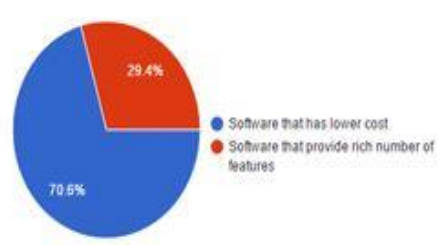

Is economy is the main factor behind piracy or not.

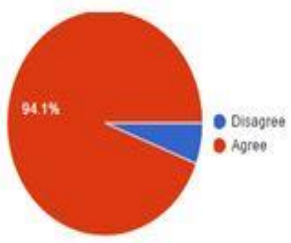

Software availability by participant's institution

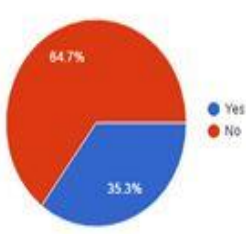

Figure 3: Users' Responses
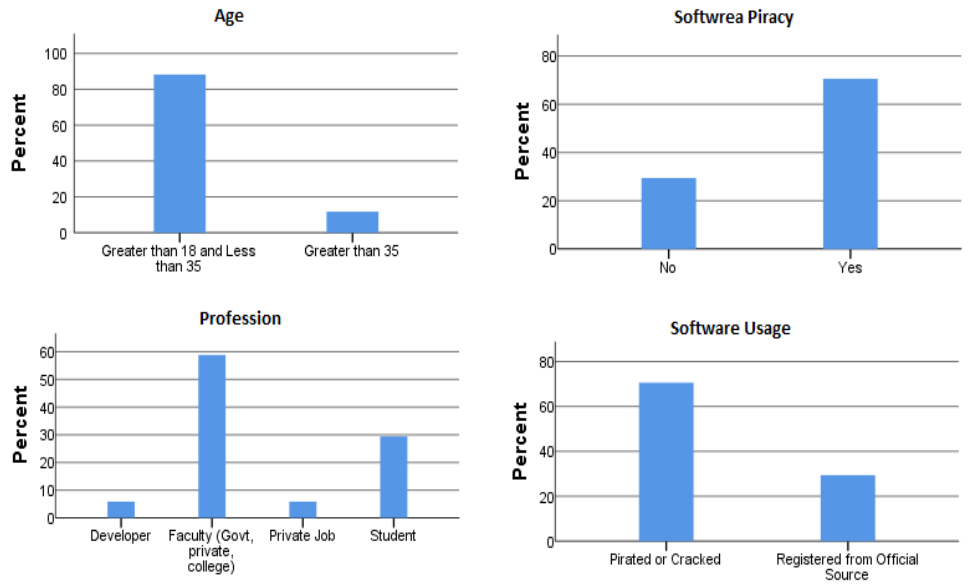

Figure 4: Charts of responses
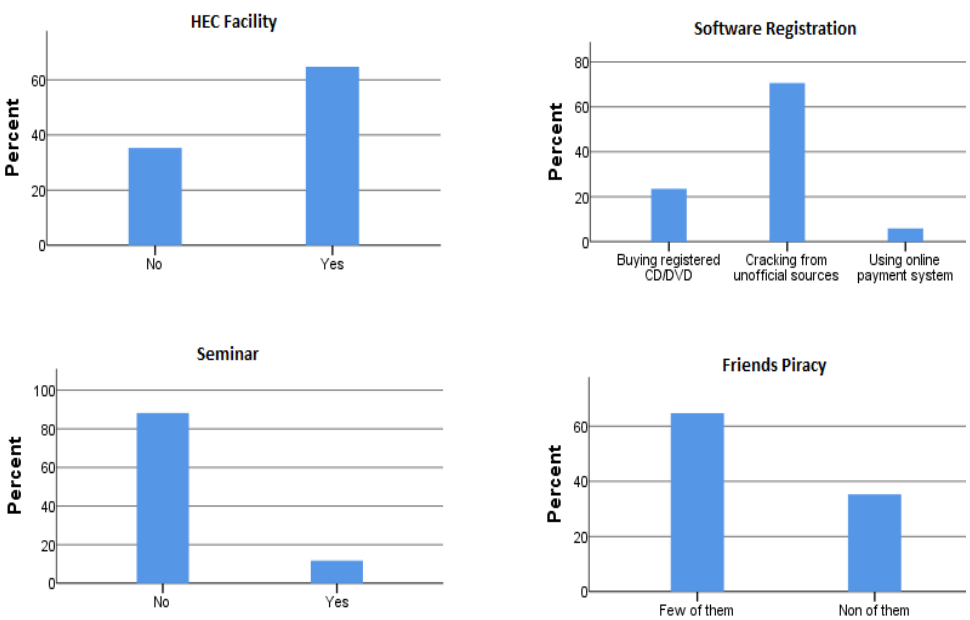

Figure 5: Charts of responses 


\begin{tabular}{|c|c|c|c|c|}
\hline & Null Hypothesis & Test & Sig. & Decision \\
\hline 1 & $\begin{array}{l}\text { The categories defined by } 1= \\
\text { Greater than } 18 \text { and Less than } 35 \\
\text { and Greater than } 35 \text { occur with } \\
\text { probabilities } 0.5 \text { and } 0.5 \text {. }\end{array}$ & $\begin{array}{l}\text { One-Sample } \\
\text { Binomial test }\end{array}$ & .000 & $\begin{array}{l}\text { Reject the } \\
\text { null } \\
\text { hypothesis. }\end{array}$ \\
\hline 2 & $\begin{array}{l}\text { The categories of } 2 \text { occur with equal } \\
\text { probabilities. }\end{array}$ & $\begin{array}{l}\text { One-Sample } \\
\text { Chi-Square } \\
\text { Test }\end{array}$ & .000 & $\begin{array}{l}\text { Reject the } \\
\text { null } \\
\text { hypothesis. }\end{array}$ \\
\hline 3 & $\begin{array}{l}\text { The categories defined by } 3=\mathrm{N}_{0} \\
\text { and Yes occur with probabilities } 0.5 \\
\text { and } 0.5 \text {. }\end{array}$ & $\begin{array}{l}\text { One-Sample } \\
\text { Binomial test }\end{array}$ & .001 & $\begin{array}{l}\text { Reject the } \\
\text { null } \\
\text { hypothesis. }\end{array}$ \\
\hline 4 & $\begin{array}{l}\text { The categories defined by } 4= \\
\text { Pirated or Cracked and Registered } \\
\text { from Official Source occur with } \\
\text { probabilities } 0.5 \text { and } 0.5 \text {. }\end{array}$ & $\begin{array}{l}\text { One-Sample } \\
\text { Binomial test }\end{array}$ & .001 & $\begin{array}{l}\text { Reject the } \\
\text { null } \\
\text { hypothesis. }\end{array}$ \\
\hline 5 & $\begin{array}{l}\text { The categories defined by } 5=\mathrm{No}_{0} \\
\text { and Yes occur with probabilities } 0.5 \\
\text { and } 0.5 \text {. }\end{array}$ & $\begin{array}{l}\text { One-Sample } \\
\text { Binomial Test }\end{array}$ & .021 & $\begin{array}{l}\text { Reject the } \\
\text { null } \\
\text { hypothesis. }\end{array}$ \\
\hline 6 & $\begin{array}{l}\text { The categories defined by } 6=\mathrm{N}_{0} \\
\text { and Yes occur with probabilities } 0.5 \\
\text { and } 0.5 \text {. }\end{array}$ & $\begin{array}{l}\text { One-Sample } \\
\text { Binomial Test }\end{array}$ & .000 & $\begin{array}{l}\text { Reject the } \\
\text { null } \\
\text { hypothesis. }\end{array}$ \\
\hline 7 & $\begin{array}{l}\text { The categories of } 7 \text { occur with equal } \\
\text { probabilities. }\end{array}$ & $\begin{array}{l}\text { One-Sample } \\
\text { Chi-Square } \\
\text { Test }\end{array}$ & .000 & $\begin{array}{l}\text { Reject the } \\
\text { null } \\
\text { hypothesis. }\end{array}$ \\
\hline 8 & $\begin{array}{l}\text { The categories defined by } 8=\text { Non } \\
\text { of them and } F \text { ew of them occur with } \\
\text { probabilities } 0.5 \text { and } 0.5 \text {. }\end{array}$ & $\begin{array}{l}\text { One-Sample } \\
\text { Binomial test }\end{array}$ & .021 & $\begin{array}{l}\text { Reject the } \\
\text { null } \\
\text { hypothesis. }\end{array}$ \\
\hline 9 & $\begin{array}{l}\text { The categories of } 9 \text { occur with equal } \\
\text { probabilities. }\end{array}$ & $\begin{array}{l}\text { One-Sample } \\
\text { Chi-Square } \\
\text { Test }\end{array}$ & .000 & $\begin{array}{l}\text { Reject the } \\
\text { null } \\
\text { hypothesis. }\end{array}$ \\
\hline 10 & $\begin{array}{l}\text { The categories defined by } 10=\mathrm{No}_{0} \\
\text { and Yes occur with probabilities } 0.5 \\
\text { and } 0.5 \text {. }\end{array}$ & $\begin{array}{l}\text { One-Sample } \\
\text { Binomial Test }\end{array}$ & .000 & $\begin{array}{l}\text { Reject the } \\
\text { null } \\
\text { hypothesis. }\end{array}$ \\
\hline 11 & $\begin{array}{l}\text { The categories of } 11 \text { occur with } \\
\text { equal probabilities. }\end{array}$ & $\begin{array}{l}\text { One-Sample } \\
\text { Chi-Square } \\
\text { Test }\end{array}$ & .011 & $\begin{array}{l}\text { Reject the } \\
\text { null } \\
\text { hypothesis. }\end{array}$ \\
\hline 12 & $\begin{array}{l}\text { The categories defined by } 12= \\
\text { Decreasing software license prices } \\
\text { and Increasing Awareness occur } \\
\text { with probabilities } 0.5 \text { and } 0.5 \text {. }\end{array}$ & $\begin{array}{l}\text { One-Sample } \\
\text { Binomial Test }\end{array}$ & .182 & $\begin{array}{l}\text { Retain the } \\
\text { null } \\
\text { hypothesis. }\end{array}$ \\
\hline 13 & $\begin{array}{l}\text { The categories defined by } 13=\text { High } \\
\text { prices of softwares and Lack of } \\
\text { awareness occur with probabilities } \\
0.5 \text { and } 0.5 \text {. }\end{array}$ & $\begin{array}{l}\text { One-Sample } \\
\text { Binomial Test }\end{array}$ & .716 & $\begin{array}{l}\text { Retain the } \\
\text { null } \\
\text { hypothesis. }\end{array}$ \\
\hline 14 & $\begin{array}{l}\text { The categories defined by } 14= \\
\text { Agree and Disagree occur with } \\
\text { probabilities } 0.5 \text { and } 0.5 \text {. }\end{array}$ & $\begin{array}{l}\text { One-Sample } \\
\text { Binomial Test }\end{array}$ & .000 & $\begin{array}{l}\text { Reject the } \\
\text { null } \\
\text { hypothesis. }\end{array}$ \\
\hline 15 & $\begin{array}{l}\text { The categories defined by } 15= \\
\text { Software that has lower cost and } \\
\text { Software that provide rich number of } \\
\text { features occur with probabilities } 0.5 \\
\text { and } 0.5 \text {. }\end{array}$ & $\begin{array}{l}\text { One-Sample } \\
\text { Binomial test }\end{array}$ & .001 & $\begin{array}{l}\text { Reject the } \\
\text { null } \\
\text { hypothesis. }\end{array}$ \\
\hline 16 & $\begin{array}{l}\text { The categories defined by } 16=\text { No } \\
\text { and Yes occur with probabilities } 0.5 \\
\text { and } 0.5 \text {. }\end{array}$ & $\begin{array}{l}\text { One-Sample } \\
\text { Binomial test }\end{array}$ & .021 & $\begin{array}{l}\text { Reject the } \\
\text { null } \\
\text { hypothesis. }\end{array}$ \\
\hline
\end{tabular}

Asymptotic significances are displayed. The significance level is .05 .

Figure 6. Hypothesis Test Summary
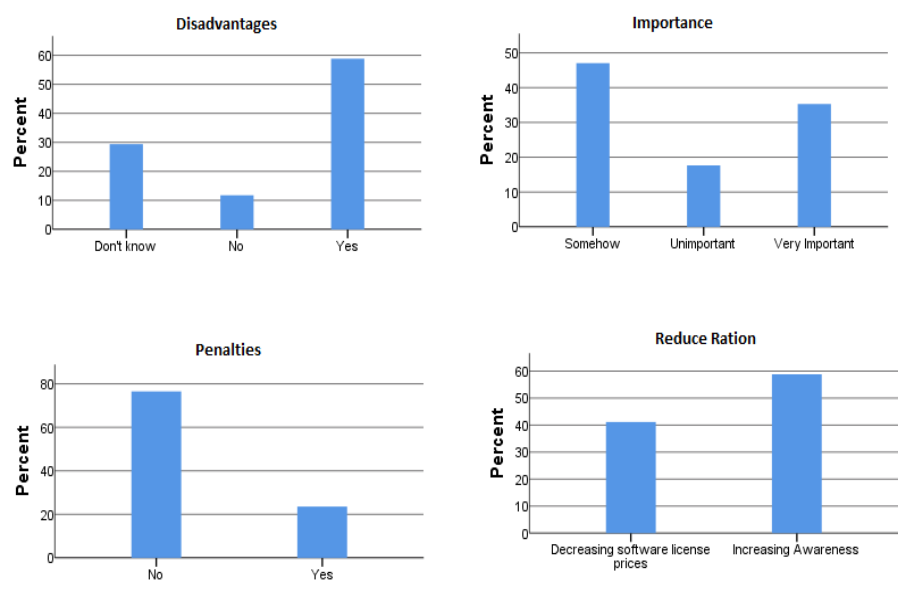

Figure 7: Charts of responses
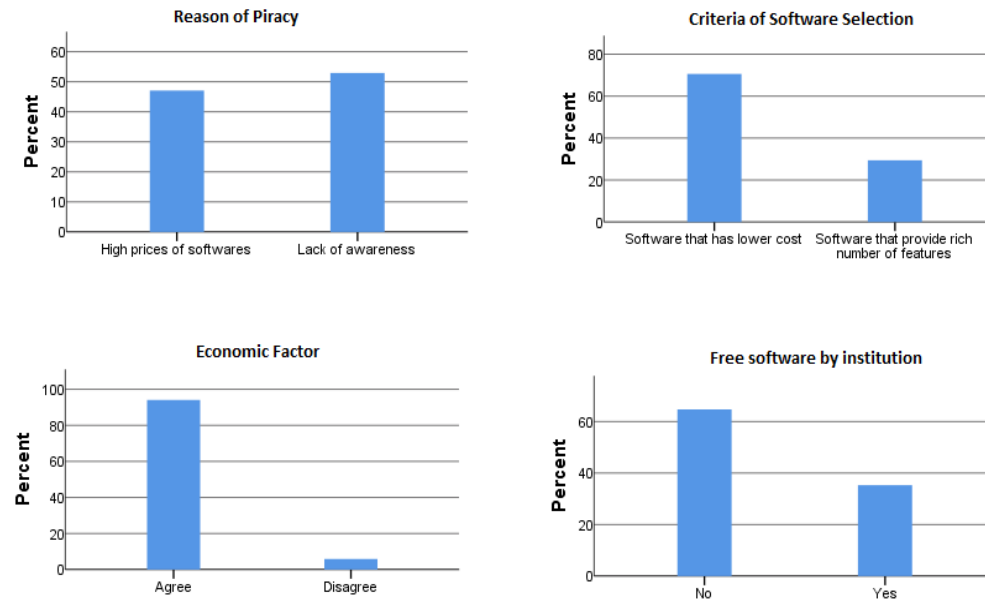

Figure 8: Charts of responses

\section{Conclusion}

The presented research aimed to focus on the awareness of software piracy in academic institutions. Survay questionnaire was used for identification of piracy level and awareness. Responses of the participant show that level of piracy is still on the high level. The main reason identified from the conducted study was the lack of knowledge about piracy disadvantages, penalties given for using piracy softwares, financial factor and awareness about piracy issue. The problem of software piracy can be tackled by increasing awareness among the public. This can be achieved by conducting seminars and workshops regarding software piracy. Other initiatives that can be taken to lower the level of software piracy includes lowering the prices of softwares, academic institution should have the facility to provide free/low cost softwares, drawbacks of pirated softwares should be highlighted to general public.

\section{Acknowledgements}

The authors would like to acknowledge Higher Education Commission of Pakistan for support of this work and for funding this project under grant No. 211249/SRGP/R\&D/HEC/2016.

\section{References}

[1] T. T. Moores and J. Dhaliwal, "A reversed context analysis of software piracy issues in Singapore," Information \& Management vol. 41, pp. 1037-1042, 2004.

[2] L. L. Gan and H. C. Koh, "An empirical study of software piracy among tertiary institutions in Singapore," Information \& Management, vol. 43, pp. 640-649, 2006.

[3] A. Mishraa, I. Akmana, and A. Yazicib, "Software piracy among IT professionals in organizations," International Journal of Information Management, vol. 26, pp. 401-413, 2006.

[4] D. Curtis, "Software piracy and copyright protection," in Wescon/94: Idea/Microelectronics New York, NY, USA, 1994, pp. 199 - 203. 
[5] S. Nazir, S. Shahzad, S. A. Khan, N. B. Ilyas, and S. Anwar, "A novel rules based approach for estimating software birthmark," Scientific World Journal, vol. 2015, pp. 1-8, 2015.

[6] G. Myles and C. Collberg, "Software Watermarking Through Register Allocation: Implementation, Analysis, and Attacks," in Information Security and Cryptology - ICISC 2003. vol. 2971: Springer Berlin Heidelberg, 2004, pp. 274-293.

[7] C. Collberg and T. R. Sahoo, "Software watermarking in the frequency domain: Implementation, analysis, and attacks," Journal of Computer Security, vol. 13, pp. 721-755, 2005.

[8] F. Liu, B. Lu, and X. Luo, "A Chaos-Based Robust Software Watermarking," in Information Security Practice and Experience. vol. 3903: Springer Berlin Heidelberg, 2006, pp. 355-366.

[9] H. Park, S. Choi, H.-i. Lim, and T. Han, "Detecting code theft via a static instruction trace birthmark for Java methods," in 6th IEEE International Conference on Industrial Informatics, 2008, pp. 551-556.

[10] H. Park, S. Choi, H.-i. Lim, and T. Han, "Detecting Java Theft Based on Static API Trace Birthmark," in Advances in Information and Computer Security. vol. 5312: Springer Berlin Heidelberg, 2008, pp. 121-135.

[11] H.-i. Lim, H. Park, S. Choi, and T. Han, "A method for detecting the theft of Java programs through analysis of the control flow information," Information and Software Technology, vol. 51, pp. 1338-1350, 2009.

[12] Y. Zeng, F. Liu, X. Luo, and C. Yang, "Software Watermarking Through Obfuscated Interpretation: Implementation and Analysis," Journal of Multimedia, vol. 6, 2011.

[13] H. Park, H.-i. Lim, S. Choi, and T. Han, "Detecting common modules in Java packages based on static object trace birthmark," Computer Journal, vol. 54, pp. 108-124, 2011.

[14] Y. Zeng, F. Liu, X. Luo, and S. Lian, "Abstract interpretation-based semantic framework for software birthmark," Computers \& Security, vol. 31, pp. 377390, 2012.

[15] S. Nazir, S. Shahzad, and L. S. Riza, "BirthmarkBased Software Classification Using Rough Sets," Arabian Journal for Science and Engineering, vol. 42, pp. 1-13, 2016.

[16] S. Nazir, S. Shahzad, I. Zada, and H. Khan, "Evaluation of software birthmarks using fuzzy analytic hierarchy process," in Proceedings of the Fourth International Multi-topic Conference, 2015, pp. 171-175.

[17] S. Nazir, S. Shahzad, Q.-U.-A. Nizamani, R. Amin, M. A. Shah, and A. Keerio, "Identifying Software Features as Birthmark," Sindh Univ. Res. Jour. (Sci. Ser.), vol. 47, 2015.

[18] S. Nazir, S. Shahzad, R. B. Atan, and H. Farman, "Estimation of software features based birthmark," Cluster Computing-The Journal of Networks Software Tools and Applications, 2017.

[19] S. Nazir, S. Shahzad, and S. B. S. Abid, "Selecting software design based on birthmark," Life Science Journal, vol. 11, pp. 89-93, 2014. 